\title{
Magten i sundhed Om sundhedsprofessionalisme i kommunale sundhedshuse
}

\section{Marie Østergaard Møller}

ProPublic

marie@propublic.dk

Møller, Marie Østergaard (2016). Magten i sundhed: Om sundhedsforståelser i de danske sundhedshuse, Tidsskrift for Forskning i Sygdom og Samfund, nr. 25, 73-99.

Artiklen undersøger, hoordan det ændrede fokus på sundhed (afstedkommet af strukturreformen $i$ 2007) har haft betydning for udviklingen af sundhedsprofessionalisme $i$ kommunale sundhedshuse og for de sundhedsprofessionelles kamp for status. Hvordan udøves sundhedsprofessionalisme $i$ fraværet af læger og deres bio-medicinske forståelsesramme, $i$ fraværet af hospitalets kliniske rammer og ikke mindst i fraværet af "diagnosen" som klassificerende og statusgivende redskab? Artiklens teoretiske afsæt er professionel udvikling og status. Teori peger her på at professionalisme fär sin endelige form i mødet med individet og de administrative, sociale og fysiske rammer, der betinger udøvelsen af aktiviteter og graden af formalisering. Artiklen undersøger hoilken status, der knytter sig til de sundhedsrelaterede aktiviteter udøvet under de lokale administrative og forvaltningsmæssige rammer $i$ sundhedshusene, ligesom det undersøges, hoilken status sundhedshuset ser ud til at have for de borgere, der kommer der. 
The power of health: Health professionalism in municipal health houses

The article examines how the altered focus on health (brought about by structural reform in 2007) has had an impact on the development of health professionalism in municipal health houses and health professionals' struggle for status? How is the health professionalism exercised in the absence of doctors and their bio-medical framework of understanding, in the absence of hospital clinical setting and not least in the absence of »the diagnosis " as a classifying and status-giving tool? The article's theoretical basis is professional development and status. Theory suggests that professionalism gets its final form in the meeting with the individual and in the meeting with the administrative, social and physical environment that determines the performance of activities and the degree of formalization. The article examines the status related to the health-related activities pursued under the local administrative and governance structures in health houses, just as it is examined what status the health house seems to have for the citizens who come there.

\section{Det kommunale sundhedsansvar}

Vores kommunale sundhedspolitik har ændret sig siden strukturreformen i 2007. Fra at handle om pleje og omsorg af de ældre, de nyfødte og deres familier handler det nu om "vores alles" sundhedsfremme, sygdomsforebyggelse og rehabilitering (Pedersen \& Rank Petersen, 2014 :276). Det er sundhedsloven, der adresserer kommunernes sundhedsfremmende og sygdomsforebyggende ansvar overfor borgerne (Sundhedsministeriet, 2010), mens det er sundhedsstyrelsen, som udstikker retningslinjerne for, hvad staten mere præcist mener, er kommunernes forpligtelser. Sygdomsforebyggelse begribes af sundhedsstyrelsen som "sundhedsrelateret aktivitet, der søger at forhindre opståen og udvikling af sygdomme, psykosociale problemer, eller ulykker, og dermed fremme folkesundheden", mens sundhedsfremme defineres som: "sundhedsrelateret aktivitet, der søger at fremme den enkeltes sundhed og folkesundheden ved at skabe rammer og muligheder for at mobilisere patienters og andre borgeres ressourcer og handlekompetence" (Tønnesen \& Det Nationale Begrebsråd for Sundhedsvæsenet. Arbejdsgruppen vedrørende Forebyggelse,Sundhedsfremme og Folkesundhed, 2005 :27).

Det kommunale sundhedsansvar fordrer således en række nye sundhedsrelaterede aktiviteter, som ikke er direkte koblet til hverken hospitalernes eller til den almene lægepraksis eller til den såkaldte biomedicinske forståelse af forholdet mellem sygdom og sundhed - ligesom sygdomsforebyggende og sundhedsfrem- 
mende sundhedsrelaterede aktiviteter ikke kræver et diagnosticeret sygt individ eller en formel adgang til at diagnosticere (Lund, Christensen, \& Iversen, 2011). Det er derimod et ansvar, der retter sig mod kommunens borgeres generelle livskvalitet, deres muligheder for at forøge deres mentale, fysiske, sociale og psykiske ressourcer og handlingskompetencer, det vil sige deres evne til at omsætte krav og holdninger til sundhedsfremmende adfærd. Omstruktureringerne handler således i første omgang om ændrede arbejdsopgaver og med dem en anderledes sundhedsforståelse, der ikke er forankret i et klassisk biomedicinsk perspektiv. Det betyder, at omstruktureringerne $i$ anden omgang kan komme til at fremme udviklingen af en ny sundhedsprofessionalisme. Dermed kommer omstruktureringerne også til at handle om magt og potentielt nye fagrelaterede hierarkier mellem sundhedsprofessionerne i og udenfor sundhedshusene.

Heri ligger kimen til en større forandring og brud med tidligere tiders sundhedsforvaltning og sundhedsforståelse, der rækker udover en forandring i en administrativ praksis og ind i de forskellige sundhedsprofessionelles interne hierarkier - herunder deres kampe om arbejdsopgaver. Men forandringen vedrører også, hvilket undersøges i nærværende artikel, en kamp om, hvem der kan anerkendes for hvad inden for sundhed samt hvilken status, der knytter sig til de sundhedsrelaterede aktiviteter udøvet under de lokale administrative og forvaltningsmæssige rammer.

Artiklen undersøger, hvordan det ændrede fokus på sundhed for alle og de ændrede strukturelle betingelser afstedkommet af strukturreformen i 2007 har haft betydning for de sundhedsprofessionelles sundhedsforståelse og for deres status. Hvordan udøves sundhedsprofessionalisme i fraværet af læger og deres bio-medicinske forståelsesramme, hospitalets kliniske rammer og ikke mindst af "diagnosen" som klassificerende og statusgivende redskab? Artiklens teoretiske afsæt er professionel udvikling og status. Teori peger her på at professionalisme får sin endelige form i mødet med individet og i mødet med de administrative, sociale og fysiske rammer, der betinger udøvelsen af aktiviteter og graden af formalisering. Endelig undersøges, hvilken status sundhedshuset ser ud til at have for de borgere, der kommer der. Artiklen er organiseret som følger: Først beskrives begreberne om status og professionalisme hernæst indsamlingsmetoden bag det empiriske materiale. I artiklens største og tredje del fremstilles resultaterne af, hvordan det kommunale sundhedsansvar er blevet organiseret siden 2007, samt de meningssammenhænge omkring sundhedshuset og dets aktiviteter, der præger såvel de sundhedsprofessionelle som de borgere, der kommer i sundhedshu- 
set. I artiklens fjerde del diskuteres resultaterne i lyset af den statusteoretiske og professionssociologiske ramme.

\section{Udvikling og udøvelse af sundhedsprofessionalisme}

Sygdom og sundhed er begreber og fænomener, der typisk beskrives "indefra" et medicinsk felts terminologi og praksis, det vil sige typisk fra de medicinskkliniske rammer på hospitaler og lægeklinikker, og hvor udvikling i begrebsanvendelser og forståelser entydigt følger det interne hierarki mellem speciallæger, almen praktiserende læger, sygeplejersker og andre sundhedsprofessionelle som for eksempel ergoterapeuter og fysioterapeuter (Lund et al., 2011). På dette felt er det væsentligste administrative, fagdidaktiske og ikke mindst statusgivende instrument "diagnosen", det vil sige magten og retten til at afgøre hvilke behandlingsmæssige foranstaltninger, der skal foretages overfor det individ, der på den ene eller anden måde er sygdomsramt. De, der behersker forståelser af sygdom og sundhed, besidder både viden og magt til at gøre bestemte fortolkninger af disse sammenhænge gældende.

Iagttagelsen af hvorfor der er viden og magt $\mathrm{i}$ at beherske bestemte kulturelle forståelser af eksempelvis sygdom og sundhed har sine rødder i moderne og postmoderne sociologi (M. Foucault, 2001; Weber, 1994; Weber, 2003). Idet viden er kilde til refleksion, overblik og konstruktion af meningssammenhænge, kan den ligesom magt få individer til at ændre selvopfattelse og ikke mindst adfærd, fordi den er en ressource, der kan skabe adgang til indflydelse på hvilke meningssammenhænge, der "får lov" til at dominere over andre (M. Foucault 1926-1984, 2000). Weber sondrede således mellem social og kulturel status, for at markere en forskel på om ens status er givet af en myndighed eller forankret i en bredere kulturel anerkendelse (Weber, 2003). Den status, der knytter sig til at have monopol på en arbejdsopgave, en foranstaltning eller en domspraksis som for eksempel "diagnosticering", kan eksempelvis gives af staten som myndighed, og betegner, hvad Weber kalder for social status. Kulturel status knytter sig derimod til den almene anerkendelse, som "monopolet" har i samfundet. Professionssociologi peger dog på at opkomsten og udviklingen af professioners sociale status ikke (alene) er givet ved statslig kontrol. Professioner er også erhverv, det vil sige ydelser og services, der gives mod betaling på et marked, som vi kender det fra mange håndværkerprofessioner, ligesom de også er sociale fællesskaber, der er knyttet sammen i specialiserede, lukkede ordener (Abbott, 1988). Endelig ser den 
funktionelle og positive professionssociologi professioner som først og fremmest håndhævere af et produkt af det civile samfunds normative orden (Durkheim \& Turner, 1992; T. Parsons, 1964: 428-479; Sciulli, 2009).

Julia Evetts peger endvidere på, hvordan man også må sondre mellem udviklingen af professioner, professionalisering og professionalisme for at begribe hvilke sociale systemer, sociale relationer og ikke mindst videnshierarkier, der betinger udfaldet af udviklingen af en ny profession (Evetts, 1999:119). Professionernes opkomst, professionaliseringsprocesser og udviklingen af professionalisme er alle drevet af bestræbelser efter magt og viden, men spørgsmålet om; hvorfor nogle og ikke andre professioner får fodfæste, hvordan de udvikler sig i samfundet, og ikke mindst hvordan individer professionaliseres, forklares af forskellige sociale processer og dynamikker ((E. Freidson 1923-2005, 2007)ref). Studiet af professioners udvikling forklares for eksempel ved samfundsprocesser, der involverer forholdet mellem stat, marked og civilsamfund, mens professionaliseringsstile kan forklares af de organisatoriske og institutionelle hierarkier, der kendetegner uddannelses- og erhvervsfeltet (Sciulli, 2009). Endelig kan professionalisme som empirisk fænomen forklares ved de betingelser for udøvelse af ydelser, der eksempelvis kendetegner rammerne for interaktioner mellem professionelle og de individer, som ydelserne er rettet mod (Wilensky, 1964). Evetts peger i forlængelse heraf på, hvordan professioners udvikling også kan forstås som udviklinger i ansvarlighedsforhold overfor faglige normer, klienter og de arbejdspladser, som professionelle er en del af - uanset om man anskueliggør en makro- meso eller et mikroforklaring på en given forandring eller stabilitet (Evetts, 1999 :126).

Professionsforskningen anvender begreber som semi-professionalisme og hybridprofessionalisme til at betegne, hvordan nye og endnu svagt etablerede professioner forandres i mødet med stærkere og veletablerede positioner, og hvordan der er en tendens til, at disse svagere professioner kobles administrativt fremfor juridisk til staten (Evetts, 1999; Evetts, 2011; E. Freidson 1923-, 2001). Det gælder for eksempel, når sygeplejeprofessionen fastholder et administrativt monopol på diverse patientrettede kerneopgaver på hospitalerne, mens lægerne fastholder et juridisk monopol på diagnosticering. Forskellen på at være administrativt og juridisk koblet til staten handler altså også om viden og magt. Hermed trækker Evetts en tråd tilbage til Weber og til hans sondring mellem statens og folkets anerkendelse som en kapital og en drivkraft, der efterstræbes blandt professionerne og af de professionelle i deres udøvelse af professionalisme (Weber, 1994). Professioner er optaget af at lukke sig om deres monofaglighed og sikre ejerskab - selv på mindre rutineprægede arbejdsopgaver såsom blodprøvetagning på hospitalerne 
eller lektiehjælp i skolen - fordi kampen om professionel status set med Webers begreber drejer sig om at afmærke fagspecifikke territorier til at kunne dominere hvilke bedømmelseslogikker, der bringes i anvendelse, når borgerne bliver til patienter og til klienter med behov for professionel hjælp (Harrits \& Larsen, 2016; Starr, 1982).

Den transformation, der sker, når borgere træder ind i en rolle som patient eller klient, er beskrevet af Talcot Parsons (T. Parsons, 1975). Han beskriver i sin professionsteori, hvordan samfundets fortsatte sociale integration afhænger af, at der findes institutionaliserede (stabile) relationer mellem professionelle og borgere, der træder ind i nogle bestemte roller. Dette er muligt, fordi de professionelle har en status, der både er forankret juridisk eller administrativt i staten og kulturelt i samfundet, ved at borgerne anerkender de professionelles position og legitimitet. Begge dele må, ifølge Parsons, være til stede, for at professionen giver mening, og for at de professionelle kan udøve deres professionalisme (T. Parsons, 1975). Men sådanne interaktioner mellem en professionel og en borger foregår også altid som et fysisk møde. Michel Foucaults klassiske studie af klinikkens fødsel viser eksempelvis, hvordan den medicinske klinik kom til at fungere som en væsentlig understøttende fysisk ramme for udviklingen af den moderne medicinske praksis (M. Foucault 1926-1984, 2000). Andre studier viser tilsvarende, hvordan fysisk indretning spejler juridiske principper og sociale konventioner, der virker adfærdsanvisende for de individer, der begår sig i rammerne (Dubois, 2010). Studiet af sammenhængen mellem fysiske rammer og social interaktion er meget præcist udfoldet i Erving Goffmans mikrosociologi om strukturelt indlejret handling (E. Goffman, 1963; E. Goffman 1922-1983, 1990; E. Goffman \& Helmreich, 2007). Her analyserer han, hvordan fysiske rammer skal forstås som en scene, der skildrer, hvilke roller der kan spilles, ligesom de indlejrede sociale forventninger i scenens opsætning skildrer hvilke roller, der ikke forventes udfyldt. Det er med andre ord ikke alene de juridiske, de administrative og de skolastiske principper, men også de fysiske rammer, der får en betydning for, hvordan professionelle bliver i stand til at udøve en særlig praksis, der med tiden kan kaldes for deres og som kan udvikles og fastholdes over tid. Det gælder for eksempel for professionelle som lærere eller advokater, der afhænger af bestemte ritualiserede fysiske rammer, som klasseværelset og domstolen for at kunne udøve deres hverv og faglige dømmekraft (E. Goffman 1922-1983, 1990).

Goffman har illustreret, hvordan fysiske rammer har kapacitet til at påvirke adfærd i hans studier af "den store indespærring" i 1960'erne, ligesom Foucault identificerede lignende mekanismer mellem en ydre organisatorisk og en indre 
mental orden blandt kriminelle i fængslet og blandt læger på klinikken (M. Foucault 1926-1984, 2000; E. Goffman \& Helmreich, 2007). De nye sundhedshuse er nok administrative og politiske konstruktioner, men de er også arenaer for interaktion og professionel ritualisering af adfærd og bedømmelser, på samme måde som fængslet og klinikken er det.

De nye sundhedsprofessionelle har allerede social status via sundhedsloven og den lokale administrative forankring i sundhedshusene. Dermed har de teoretisk set allerede de formelle betingelser for at udøve professionelle aktiviteter. Spørgsmålet er, om de også har kulturel status? Anderkender borgerne de sundhedsprofessionelles praksis og i givet fald hvordan og hvorfor? Hvordan klarer disse nye sundhedsprofessionelle sig i deres sociale og kulturelle kamp om status? Finder de nye veje til status, eller (for)bliver de lavest rangerende i et symbolsk lægefagligt hierarki, hvor de ingen magtfulde redskaber har, der kan erstatte diagnosen? Bliver de som betjente uden pistoler, lærere uden bøger eller findes der andre magtfulde redskaber i de nye sundhedshuse, der kan udruste dem til videns- og magtfulde møder med kommunens borgere?

I det følgende beskrives hvilken metode og hvilket datagrundlag ovenstående spørgsmål undersøges med.

\section{Metode og materiale}

Siden 2007 har hver anden dansk kommune etableret et sundhedshus for at fremme sundhed og forebygge sygdom blandt kommunens borgere. I stedet for at undersøge hvordan sundhedsprofessionelle håndhæver professionel status udenfor det medicinske felts institutionelle orden (udenfor hospitalet og den lægefagligt dominerede klinik), undersøges strategisk udvalgte kommunale sundhedshuse. Alt data er indsamlet i perioden december 2013 - juni 2014. På baggrund af et telefonsurvey, hvor samtlige 98 kommuner blev ringet op og spurgt til, hvordan de har organiseret deres kommunale sundhedsansvar, blev der identificeret 48 kommuner med et fysisk sundhedshus. Ud af disse 48 kommuner blev 19 sundhedshuse udvalgt til yderligere kvalitative undersøgelser. De blev udvalgt således, at de 19 sundhedshuses organisatoriske forskelle var så fremtrædende som muligt på parametrene: myndighedsstruktur, ledelse og administrative rutiner, for på den måde at sikre mættet data til beskrivende analyser af hvilke typer af sundhedshuse materialet indeholder. Fordelen ved at udvælge på denne måde har været at fange de mange måder, kommunerne har organiseret sig på, samtidig 
med at eventuelle ligheder mellem borgernes og de professionelles forventninger og aktiviteter kan sammenlignes med organisatorisk struktur. Ved at undersøge meget forskellige sundhedshuse, der opererer under de samme juridiske principper og administrative hensyn, styrkes muligheden samtidig for at forstå rækkevidden af de forskelle i forventninger og aktiviteter, der kan identificeres blandt sundhedsprofessionelle og borgere i de 19 undersøgte sundhedshuse.

\begin{tabular}{|l|l|l|l|}
\hline & Sundhedshus & $\begin{array}{l}\text { Ingen } \\
\text { Sundhedshus }\end{array}$ & $\begin{array}{l}\text { Sunhedshus på } \\
\text { vej }\end{array}$ \\
\hline Nordjylland & $7(3)$ & 4 & 0 \\
\hline Midtjylland & $12(5)$ & 5 & 2 \\
\hline Syddanmark & $10(4)$ & 12 & 1 \\
\hline Hovedstaden & $11(3)$ & 18 & 0 \\
\hline Sjælland & $8(4)$ & 7 & 1 \\
\hline Total & $48(19)$ & 46 & 4 \\
\hline
\end{tabular}

Tabel 1: Sundhedshuse i danske regioner. Celleindhold: Danmarks 98 kommuner. Tal $i$ parentes angiver antal observerede sundhedshuse.

Artiklens analyser er baseret på on-site observationer og interview med sundhedsprofessionelle og borgere fra de 19 sundhedshuse. Observationerne er begrænset af kun at vare mellem 1 og 2 timer, men et hverdagsblik er efterstræbt ved at observere i det tidsrum, hvor der er flest aktiviteter i husene. Derudover var det også en selvstændig hensigt at observere den fysiske indretning, hvilket kunne gøres inden for den observerede tidsramme uafhængig af social interaktion. Der er brugt vignetmetode og semistruktureret interviewmetode til at fange sundhedsprofessionelle og borgernes forventninger til aktiviteterne i sundhedshuset, ligesom spørgsmålene har rettet sig mod at forstå såvel borgernes som de professionelles opfattelse af sundhed, forebyggelse og deres refleksioner omkring sundhedshuset som en ramme om de nye kommunale sundhedsaktiviteter. Midt $\mathrm{i}$ interviewet blev både de sundhedsprofessionelle og borgerne præsenteret for en beskrivelse af et sundhedshus og dets indretning i en såkaldt vignethistorie. I de fleste tilfælde læste interviewpersonen selv vignetten op fra en seddel, de fik af intervieweren. I enkelte tilfælde blev vignetten læst op af en tolk, idet borgeren ikke kunne læse tilstrækkeligt dansk selv. 
Vignetterne beskriver to sundhedshuse, der er indrettet forskelligt såvel organisatorisk som fysisk, og de er således blevet brugt til at tale med de professionelle og med borgerne om betydningen af organisatoriske forskelle for deres forventninger til hvilke aktiviteter, der skal være i et sundhedshus, og til hvad aktiviteterne i sidste ende skal gøre for borgerne. På den måde kan det undersøges, hvorvidt deres sundhedsopfattelser på nogen måde hænger sammen med den måde, sundhedsaktiviteterne organiseres på (se vignetter i appendiks).

Der blev i alt interviewet 36 sundhedsprofessionelle og 22 borgere, som var udvalgt efter en bekvemmelighedsstrategi (Weiss, 1994). De sundhedsprofessionelle blev dog udvalgt efter deres opgavefunktion og profession, hvor det blev tilstræbt at interviewe minimum 2 professionelle med forskellig faglighed i hvert sundhedshus, mens der ingen kriterier, udover tilgængelighed, blev anvendt $\mathrm{i}$ forhold til valg af borgere. Det forholdsvis lave antal borgerinterview hænger således sammen med, at der mange gange ikke var særlig mange borgere tilstede i sundhedshuset på tidspunktet for observation og interview med de sundhedsprofessionelle.

Der er anvendt en to-trins analysestrategi som fortolkningsbase (Lofland, 2006). Først gennemførtes en åben kodning af feltnoter og transskriberede interviews med fokus på at identificere sundhedshusenes indretning, borgernes og de sundhedsprofessionelles beskrivelser og præferencer for sundhedsaktiviteter. Denne første eksplorative analyse blev herefter anvendt som basis for en systematisk og inklusiv kodning af hele materialet på dimensionerne "diagnosereferencer", "lægereferencer", "medicinske meningssammenhænge", "sundhedspædagogiske meningssammenhænge" og "vignetterespons" (se kodeliste i appendiks). Denne blev slutteligt sammenlignet med sundhedshusenes fysiske indretning i forhold til at undersøge, om der er mønstre i, hvordan forventninger og aktiviteter fordeler sig i forhold hertil (Charmaz, 2006; Miles, Huberman, \& Saldaña, 2014).

\section{Fysiske rammer og meningssammenhænge i sundhedshusene}

Telefonsurveyet viser, at kommunerne i 2013 har valgt mange forskellige løsninger og institutionelle indretninger af deres nye kommunale sundhedsrelaterede aktiviteter. Nogle har valgt at indrette busser, bibliotekshjørner, ældrecentre og kommunale hjemmesider, mens andre har valgt at bygge deciderede sundheds- 
huse (tabel 1; kode: indretning). Sundhedsaktiviteterne på tværs af de 19 udvalgte sundhedshuse er således også præget af en række forskellige sundhedsaktiviteter relateret til motion, livsstil, uddannelse, sociale aktiviteter eller til ernæring, ligesom de sundhedsprofessionelle, der arbejder i sundhedshusene, har mange forskellige uddannelsesmæssige baggrunde (se fagprofessionalisme i sundhedshusene i appendiks). Udover fagspecifikke funktioner indenfor for eksempel fysioterapi eller kostvejledning udfylder de professionelle også mange organisatoriske funktioner (kode: arbejdsopgaver). De kommunikerer med forskellige dele af kommunen, de netværker med private aktører omkring arrangementer og kursusforløb i sundhedshusene, ligesom enkelte professionelle også fortæller om, hvordan de "turnerer" blandt de lokale alment praktiserende læger for at informere omkring, hvilke typer af service og indsatser de sundhedsprofessionelle i sundhedshusene kan tilbyde borgerne. En sundhedsprofessionel beskriver, hvordan hun tror borgerne finder frem til dem på sundhedshuset:

Altså, for det første, så har jeg været ude og holde foredrag. Nogle steder her $i$ [byens navn] og omegn. (...). Og så har vi brochurer (...), som vi har stående herude, ikke også, og dem har jeg så også været ude og lægge rundt $i$ [byens navn] og $i$ [navn på by]. Og rundt omkring ved legehusene og sådan noget. Og så har vi en hjemmeside - og facebook er vi også på (M4.37)

Selvom de sundhedsprofessionelle hænger meget selvforståelse op på de aktiviteter, de tilbyder borgerne, så har de også en fælles sundhedsprofessionel identitet omkring det at være brobygger mellem borgerne og samfundet omkring dem (kode: fælles professionalisme). Det at være brobygger hænger sammen med at have en særlig organisatorisk kapacitet, som på mange måder minder om de kriterier for hybrid-professionalisme, der betegner professionelle, der både er orienterede mod det fag, de er uddannet inden for, men også mod sundhedshuset som organisation (Evetts, 1999; Schott, Van Kleef, \& Noordegraaf, 2015).

\section{Forskellige rammer}

Observationerne af de 19 sundhedshuse viser to dominerende måder at organisere det kommunale sundhedsansvar på. Disse to måder svarer til beskrivelserne i de to vignetter. Den ene type har en flad organisatorisk struktur og har vignette A's forsamlingshusagtige lokale træk, mens den anden type ligner en medicinsk- 
klinisk organisation, der minder om vignette B. Der er også huse, som enten ikke ligner disse eller som er en blanding med træk fra begge typer. I de følgende analyser vil fokus være på henholdsvis det lokale (der ligner vignette A) og det medicinsk-kliniske sundhedshus (der ligner vignette B). Materialet er klassificeret i forhold til disse træk, og her viser tabel 2, hvordan de 19 sundhedshuse og dermed de sundhedsprofessionelle og borgere, der er blevet interviewet i og omkring husene, fordeler sig på de to hovedtyper.

\begin{tabular}{|c|c|c|c|c|}
\hline Datakilde & $\begin{array}{l}\text { Det medi- } \\
\text { cinsk-klini- } \\
\text { ske }\end{array}$ & Det lokale & Mix & I alt \\
\hline $\begin{array}{l}\text { Observerede } \\
\text { sundheds- } \\
\text { huse }\end{array}$ & $\begin{array}{l}\text { S2, Sj1, Sj2, } \\
\text { M1, H1, N2, } \\
\text { N1, H3 }\end{array}$ & $\begin{array}{l}\text { M4, S4, M5, } \\
\text { M3, M2, N3 }\end{array}$ & $\begin{array}{l}\text { S1, Sj4, Sj3, S3, } \\
\text { H2 }\end{array}$ & 19 \\
\hline $\begin{array}{l}\text { Interviewede } \\
\text { sundhedspro- } \\
\text { fessionelle }\end{array}$ & $\begin{array}{l}\text { N2.25, H3.3, } \\
\text { M1.35, H1.55, } \\
\text { Sj2.10, Sj1.20, } \\
\text { Sj1.21, N1.22; } \\
\text { S2.48, Sj2.9, } \\
\text { N2.24, H3.4, } \\
\text { S2.47, N1.58 }\end{array}$ & $\begin{array}{l}\text { N3.29, M3.41, } \\
\text { N3.28, M5.40, } \\
\text { M2.32, M3.42, } \\
\text { M2.33, M4.37, } \\
\text { M4.38, M4.39, } \\
\text { M3.43, S4.54, } \\
\text { M5.57 }\end{array}$ & $\begin{array}{l}\text { Sj4.17, H2.6, } \\
\text { H2.5, Sj3.13, } \\
\text { Sj3.12, S1.45, } \\
\text { S3.49, Sj4.16, } \\
\text { S1.56 }\end{array}$ & 36 \\
\hline $\begin{array}{l}\text { Interviewede } \\
\text { borgere }\end{array}$ & $\begin{array}{l}\text { H1.1, Sj1.18, } \\
\text { Sj1.19, N2.23, } \\
\text { M1.34, S2.46, } \\
\text { H3.2, H32y, } \\
\text { Sj2.7, Sj2.8 }\end{array}$ & \begin{tabular}{|l} 
N3.26, N3.27, \\
M2.30, M2.31, \\
M4.36, S4.50, \\
S4.51, S4.52
\end{tabular} & $\begin{array}{l}\text { S1.44, Sj3.11, } \\
\text { Sj4.14, Sj4.15 }\end{array}$ & 22 \\
\hline
\end{tabular}

Tabel 2: Fordelingen af sundhedshuse og interviewpersoner på organisationstype. Celleindhold: Observationer og interviews. Alle sundhedshuse og interviewpersoner er anonymiserede. Bogstaver indikerer region ( $N=$ Nordjylland, $M=$ Midtjylland, $S=$ syddanmark, $H=$ Hovedstaden og $S j=$ Sjelland), mens numre erstatter sundheds- og interviewpersonnavn.

Som det fremgår af tabellen kan seks af de 19 sundhedshuse karakteriseres som lokale, otte som kliniske og fem som en blanding mellem disse to eller andre må- 
der at organisere sundhedshus på. I det følgende vil de to dominerende sundhedstypers karaktertræk præsenteres.

\section{Det medicinsk-klinisk organiserede sundhedshus}

Observationer fra S2, Sj1, Sj2, M1, H1, N2, N1, H3 viser sundhedshuse, der typisk hører til i nedlagte hospitals- eller kommunebygninger. De er ofte fleretagers organisationer med tilhørende store parkeringspladser og lidt buskads. Som man også kender det fra hospitaler og fra andre typer af større offentlige bygninger, så er det første, man møder ved indgangen et stort oversigtskort med anvisninger til, hvordan man finder frem til de forskellige instanser, der har til huse i bygningen. De medicinsk-klinisk organiserede sundhedshuse er mange gange mere centralt placeret og forholdsvis lettere at finde, end hvad der kendetegner den anden dominerende hovedtype, der benævnes "det lokale sundhedshus".

På baggrund af observationsnoterne ser det ud til, at sundhedshuse, der er medicinsk-klinisk organiserede, har en mere transparent myndighedsstruktur sammenlignet med det lokale sundhedshus. Det vil sige, at det er tydeligt selv ved indgangen til huset, hvem der er underordnede og overordnede hinanden i huset. Denne type sundhedshus har også et klassisk venteværelse, hvor besøgende i huset mødes af en skranke, der er designet til at understøtte receptionistens indslusning af borgerne ind i den besøgsrolle, de forventes at udfylde under deres besøg i huset. Denne sluse vedrører ikke alene en fysisk overgang fra ude til inde, men også en symbolsk overgang fra at være borger til at være klient, der modtager sundhedsydelser fra en professionel. Slusen fungerer på den måde som, hvad Goffman kalder for, en scene, der iscenesætter bestemte handlinger og adfærd samt undertrykker andre - for eksempel hvis en borger valgte at ignorere skranken og passere receptionisten uden at anerkende 'scenens opsætning' og dens spilleregler. Denne transformation er velbeskrevet i markarbejderteori og handler dybest set om at stadfæste et tydeligt og transparent magtforhold mellem en myndighed og dets subjekt, således at der ikke hersker tvivl om, hvilke adfærdsforventninger og spilleregler, der gælder (Dubois, 2010; Lipsky, 2010). 


\section{Det lokalt organiserede sundhedshus}

Observationer fra M4, S4, M5, M3, M2, N3 viser sundhedshuse, der har mere til fælles med et klassisk forsamlingshus end med et hospital. De ligger ofte sammen med andre lokale tilbud såsom børnehaver og/eller sportshaller. Mange af de lokalt organiserede huse har også udendørsfaciliteter som basketballbaner, grillpladser og legepladser. Selvom de også er centralt beliggende i byerne, så er de generelt meget sværere at finde end de medicinsk-klinisk organiserede huse. Det hænger tilsyneladende sammen med, at de medicinsk-klinisk organiserede huse er i bygninger, der længe har været en del af etablerede offentlige tilbud, mens det langt fra altid er tilfældet med de lokalt organiserede sundhedshuse.

De lokalt organiserede sundhedshuse adskiller sig også fra de medicinsk-klinisk organiserede sundhedshuse ved at være horisontalt organiserede med en leder, der tager sig af alle husets faciliteter og koordineringer af aktiviteter internt i huset (kode: indretning). Nogle huse har en skranke, som er typiske i de medicinsk-klinisk organiserede sundhedshuse, mens de fleste har møblerede cafeer eller åbne rum med direkte adgang til forskellige aktiviteter i stedet for et modtagelsescentrum.

I modsætning til de medicinsk-klinisk organiserede sundhedshuse, som er henvisningsstyrede via det regionale og kommunale system (i praksis er det kun borgere med en henvisning fra enten læger eller sagsbehandlere, som kan få adgang til de sundhedsaktiviteter, der udbydes i sundhedshuset), så er der fri adgang fra gaden i de lokalt organiserede sundhedshuse.

De sundhedsaktiviteter, der udbydes i de lokalt organiserede sundhedshuse, er typisk ikke organiseret eller administreret omkring diagnoser og behandling, men først og fremmest omkring uddannelse i selvhåndtering af eksempelvis dårlig ryg, KOL eller af diabetes omkring kost og motion. Af den forskel følger også en forskel i typer af interaktioner mellem borgere og sundhedsprofessionelle i sundhedshusene. Set med Goffman begreber om scene og selvfremstilling er rollerne i de lokalt forankrede sundhedshuse mindre indstuderede sammenlignet med rollerne i det medicinsk-kliniske sundhedshus (E. Goffman 1922-1983, 1990). I de lokalt organiserede sundhedshuse er interaktionerne således langt mindre ritualiserede sammenlignet med interaktionerne i de medicinsk-klinisk organiserede sundhedshuse, hvor borgerne kommer ind i huset, sætter sig ned og venter, modtager en ydelse og forlader huset igen umiddelbart derefter. I de lokalt organiserede sundhedshuse bliver borgerne nødet af den fysiske indretning til at blive og snakke med nogle af de andre borgere eller med de ansatte i huset. De ansatte, 
det vil sige de sundhedsprofessionelle, bruger heller ikke en ritualiseret samtaleeller præstationsform overfor borgerne, som det sker i de medicinsk-klinisk organiserede sundhedshuse. De er "overalt", ligesom borgerne nogle gange kommer i huset for at købe en kop kaffe eller for at sætte en seddel op på en opslagstavle. De fysiske rammer fremhæver således bestemte interaktionsformer og ejerskabsforhold i forhold til huset som territorium end i de medicinsk-klinisk organiserede sundhedshuse, og det viser, hvad Goffman forklarer som en social mekanisme, der består i, at fysiske rammer stimulerer interaktionsformer (1990: 34). På denne måde viser observationerne, at de lokalt organiserede sundhedshuse har en række fællestræk med det klassiske forsamlingshus, der er karakteriseret ved at være det lokale samfunds fælleseje, og ved at der foregår sociale aktiviteter, der ikke kommer nogen specifik aktør til gavn. I modsætning hertil spejler det medicinskklinisk organiserede sundhedshus på mange parametre den medicinske kliniks fysiske og sociale indretning, der er karakteriseret ved først og fremmest at tilhøre en aktør og ved at være rammen om meget specialiserede aktiviteter uden andre sociale formål.

\section{Medicinske meningssammenhænge}

Både i interviewene med de sundhedsprofessionelle og med borgerne er der eksempler på, hvordan sundhed tænkes i en modsætning til sygdom (kode: medicinsk diskurs). Den medicinske diskurs, det vil sige den sammenkædning af ord og begreber, der tilsammen skaber en forståelse af sundhed, består ikke overraskende af mange lægereferencer og diagnosereferencer, om end de konkrete meningssammenhænge langt fra altid drejer sig om ætiologi eller om decideret fagdidaktik.

Når borgerne trækker på en medicinsk diskurs, så fokuserer de på at sundhed afhænger af effektive behandlinger og medicinsk ekspertise. Sundhedshuset beskrives som et alternativ til et hospital eller en klinik. Folk forstås her som værende ansvarlige for deres egen sundhed, som også begribes som motion og som fravær af sygdom. Diagnostisk kompetence anses her som værende en afgørende forudsætning for sundhedsfaglig status (kode: reproducerende medicinsk diskurs).

Borgerne taler typisk i medicinske meningssammenhænge, når de forklarer, hvad de forventer sig af sundhedshuset, og når de fortæller om, hvad de forstår ved sundhedsfremme, forebyggelse og ved sundhedsaktiviteter generelt (kode: 
ærinde). En borger, der taler i medicinske meningssammenhænge om sundhed, ser sundhedshuset som et sted, han har adgang til for at få styr på sit kolesteroltal, ligesom det er et sted, han kan få viden om, hvordan han opnår og vedligeholder sit vægttab: "Stedet er jo en fantastisk mulighed for, at jeg kan tabe mig" (Sj3.11).

De borgere, der taler om sundhed i lægefaglige og biomedicinske termer, anerkender de sundhedsprofessionelle som aktører på sundhedsmarkedet på lige fod med lægerne, og de ser dem ikke som det næstbedste alternativ til et "reelt" behandlingstilbud (kode: kulturel status).

\section{I: Kan du beskrive hoordan det er at komme i sundhedshuset?}

R: Ehm, altså, for det forste er det jo nogle fantastiske trænere, og det er hele tiden motivation til at gøre, hoad du kan. Der er ikke noget med skæld ud eller grim tale. Og så er du jo også sammen med nogle, der har samme sygdom "I: ja". Og jeg kan forstå på nogle af dem, [at der i] deres omgivelser ikke ligesom er forståelse for, hvad deres sygdom er for noget, så nogle føler afmagt når de siger: "Jeg kan ikke løfte det der, eller jeg kan ikke gå så langt". Ehm, og jamen, så hjælper det at snakke med andre, der har det på samme måde. Så det er rigtig godt det her. Rigtig, rigtig godt. (Sj4.15)

Det tyder på, at de sundhedsprofessionelle I det pågældende sundhedshus anerkendes af denne borger for deres faglighed, og at det med Webers termer kan tyde på, at de har en vis kulturel status i samfundet (Weber, 2003). Når de sundhedsprofessionelle trækker på en medicinsk diskurs, så gør de det primært for at opponere mod en dominerende lægefaglig dominans. De fokuserer blandt andet på at beskrive arbejdsbetingelserne i de etablerede sundhedssystemer (hospitalerne) som dårlige og fortravlede og som manglende et menneskeligt perspektiv med et alt for intenst fokus på behandlinger. Ved at italesætte hospitaler som inkompetente til at understøtte menneskers sundhedsudvikling kan de på den måde fremhæve sundhedshuset som et konstruktivt og fremsynet alternativ (kode: opponerende medicinsk diskurs).

Mange af de sundhedsprofessionelles referencer knytter for eksempel an til koordination og samarbejde, såsom når det understreges, at det er "nødvendigt at samarbejde med lægen", eller "lægen fraholder mænd i at komme i sundhedshuset", eller eksplicit til den diagnostiske magt lægerne har, som betyder at "uden henvisning kommer folk, som ikke kan få en diagnose fra lægen" (kode: lægereferencer).

De sundhedsprofessionelle kan på den måde distancere sig fra især de praktiserende læger, som flere henviser til vil modarbejde dem. De beskriver, hvordan de 
oplever, at de praktiserende læger bruger deres diagnostiske magt til at frakende de sundhedsprofessionelle i sundhedshusene deres legitimitet som udøvere af sundhedsfremmende eller sygdomsforebyggende aktiviteter, som det også antydes i følgende uddrag fra en sygeplejerske i et lokalt organiseret sundhedshus:

\section{I: Hvordan fär borgeren adgang til centeret - er det elektronisk?}

R: »nej de kommer fra lægen: 'min læge sagde, at jeg skulle gå herop med denne her seddel'. Det er fordi vi har stillet, vi har en, vi vil gerne beholde, vi vil beholde sundhedsfremme som en tænkning herinde, så hvis borgerne skal på kursus hos os, så skal de være motiverede for det. Så kan det ikke nytte noget, at lægen henviser til for eksempel KOL-forløbet. Så afholder vi en afklarende samtale, som vi sætter en time af til hver gang, og så finder vi ud af, hvad der er det rigtige tilbud for borgeren. Det er ikke sikkert, at det er $i$ vores regi. (M3.41)

Dette underbygges i deres referencer til diagnosen som et redskab, der ikke mere begribes som et rent fagdidaktisk redskab og bedømmelseslogik, men også som et administrativt magtmiddel, som når en sundheds- og ernæringskonsulent fra et medicinsk-klinisk organiseret sundhedshus kritiserer, hvordan det alligevel ender med at være en diagnostisk bedømmelseslogik, der bestemmer, hvordan de udøver deres sundhedsrelaterede aktiviteter i sundhedshuset:

[D]et er skruen uden ende. Altså, jeg kan da også nogle gange tænke, at vi laver godt nok mange tilbud. Vi kan næsten blive ved med at lave tilbud, og laver vi for mange tilbud? Øhm, altså, det er jo næsten, man skal jo efterhånden have et tilbud på hver eneste lille diagnose man kan stille. Og så bliver det pludselig meget sygdomsorienteret. Så er det pludselig på grund af nogle diagnoser at vi laver noget. Og så trækker det over i noget sygdom. Hvor jeg synes at så kan vi blive ved. (Z2.10)

Andre sundhedsprofessionelle påpeger, hvordan "lægen er en barriere for borgene i forhold til at søge hjælp" (kode: lægereferencer), underforstået at lægerne udgør en barriere for, at de reelt er tilgængelige for borgerne. Selvom de sundhedsprofessionelle ikke oplever deciderede sammenstød med det medicinske felt i det daglige, så er der en erkendelse af, at på trods af at man arbejder indenfor rammerne af et sundhedshus med fri borgeradgang, så afhænger legitimiteten af deres ydelser (stadig) af de alment praktiserende lægers velvillighed og anerkendelse af dem, idet borgerne hovedsagelig forstår sundhed inden for en klassisk 
medicinsk diskurs. En fysioterapeut udtrykker eksempelvis sin frustration over at skulle oversætte sin sundhedsaktivitet til en lægefaglig logik på følgende måde:

Ja - det kunne jeg også godt. Men jeg synes at - ja jeg synes faktisk det mangler det her med, at have-Borgerne, NEJ ik' borgernes patientforeninger med. Og så er jeg ked af, at de kun kan henvise fra praktiserende læge. Eller kommunal sagsbehandler (I: ja) Det synes jeg er ærgerligt (I: ja) fordi det er der mange der, - ja, det er jo faktisk som, hvad hedder det, motion på recept, startede herude ik'. Og det der var rigtig svært for, motion på recept, det var jo. Det siger noget om, at de praktiserende lager de skal VILLE det her tilbud, førend de kan henvise til det (I: okay) Og det er jo en EKSTREM barriere (I: ja) som motion på recept kom jo ALDRIG op og køre optimalt, fordi praktiserende lager synes det var noget fis (I: ja) og skulle mene at, motion kan være, ja - et virkningsmiddel ik' (I: Ja) kontra deres medicin (Sj3.13)

Det er de sundhedsprofessionelles erfaring, at borgerne opsøger lægen, når de oplever selv mindre fysiske, sociale og psykiske problemer og at det får den konsekvens for sundhedshusene, at hvis lægerne ikke anbefaler sundhedshuset, så udgør de en reel barriere for, at borgerne nogensinde finder frem til sundhedshuset og til de aktiviteter, der tilbydes her. De sundhedsprofessionelle forklarer årsagen hertil med, at nogle af lægerne ikke kender til sundhedshusene og ikke ved hvad de tilbyder, men også med at nogle af dem decideret modarbejder dem og miskender deres eksistens på sundhedsmarkedet, som citatet ovenfor også viser. Det kan med Evetts teori, om at professionernes styrke hænger sammen med, hvor etablerede de er, og hvor stor symbolsk magt de har i samfundet, tyde på, at når de sundhedsprofessionelle afkræves at bruge lægernes recept som system og praksis til at klassificere behandling, så udstilles deres behandling som mindre værd, fordi den bliver vurderet ud fra en lægefaglig standard om at behandling skal fungere på recept. Det ender derfor med at behandlingen ikke anerkendes som en legitim sundhedsaktivitet, og at den dermed heller ikke får succes (Evetts, 1999).

Det betyder, at de sundhedsprofessionelle i sundhedshusene nok har en social status via deres administrative forankring i kommunen og deres juridiske forpligtelse i sundhedsloven til at fremme sundhed blandt kommunens borgere, men de mangler status til at markere sig i forhold til den lægefaglige dominans. Det betyder også, at der nogle gange opstår konflikter.

En sygeplejerske fra et medicinsk-klinisk organiseret sundhedshus fortæller om en situation, hvor hun udøver sit eget skøn over, hvad en henvist borger skal 
modtage af sundhedsrelaterede aktiviteter, der udvikler sig til en reel konflikt med en læge:

Hvem skal rydde op, hvem har ansvaret? Det kan vi jo også snakke om her. Hvad er et sundhedsfagligt ansvar? Jeg har engang haft en lage i røret, der ville indberette mig til sundhedsstyrelsen, fordi han havde henvist en borger til rygestop, og så havde jeg ikke sendt borgeren på rygestopforløb, men han var kommet ind på et andet forløb, der hed hverdag $i$ forandring, hvor man ikke arbejdede med rygestop, fordi det ville han ikke. Og så kan man sige, at det kræver, at man har modet til at sige: 'jamen jeg har egentlig passet min sundhedsfaglige opgave og jeg har stadig borgeren i tale, og jeg taler sundhed med ham, men det er $i$ et noget bredere perspektiv end rygestop', men jeg tror jo, at hvis jeg kan få en god relation til ham, og han har tillid til mig, så kan det jo godt være, at han på et tidspunkt godt vil snakke om rygning med mig, for han er jo ikke dum. Han ved jo godt, at det gør ham skidt og syg. Ja« (M1.35)

Her opstår en konflikt mellem en sundhedsprofessionel og en læge, der mener, hun ikke lever op til sit sundhedsfaglige ansvar, når hun ikke følger hans skøn af, hvilke aktiviteter borgeren bør lave. Kampen om sundhedsforståelse og bedømmelseslogik kommer således meget eksplicit til udtryk her, og selvom udsagnene har karakter af at være i opposition til en medicinsk meningssammenhæng, så sker sygeplejerskens betegnelse af sundhedsprofessionalisme netop via en medicinsk meningssammenhæng. Denne måde at opponere mod en lægefaglig dominans som krog til at positionere sig selv som sundhedsprofessionel i et sundhedshus gælder i ovenstående tilfælde, men det karakteriser også materialet på tværs af sundhedshusene (kode: opponerende medicinsk diskurs).

Men materialet viser også en anderledes måde at tale om sundhed og om sundhedshuset på, der ikke kan fortolkes som hverken en opposition eller en reproduktion af en medicinsk diskurs.

\section{Sundhedspædagogiske meningssammenhænge}

Selvom mange borgere og sundhedsprofessionelle spontant griber til medicinske referencer og begreber for sundhed, når de beskriver deres forventninger til sundhedshuset og til hinanden, så er der også blandt interviewpersonerne en anden måde at tale om sundhed på. I modsætning til den medicinske diskurs beskrives 
sundhed også i, hvad jeg har kaldt for sundhedspædagogiske meningssammenhænge.

Når de sundhedsprofessionelle trækker på en sundhedspædagogisk diskurs, så fremhæver de det hele menneske og på at omsætte helhedsorienterede tilgange til sundhedsudvikling, som det for eksempel kommer til udtryk hos en fysioterapeut, der arbejder i et blandet sundhedshus:

Fordi det der med ik' og - - når det bliver, klinikker, altså små enheder, så - - ser man også meget fagligt og KUN fagligt, på sin egen lille, og ikke det her helhedsorienterede billede, som jeg oplever vi har i livsstilsteamet, - - og det kan der jo både være fordele og ulemper ved, det har vi jo lige snakket om (I: ja) at det er godt at kunne se fagligheden og give den faglighed vi har, men det er også vigtigt at kunne se alle de her andre ting $i$ et menneske, at det ikke kun er motion, der er vigtigt. Men at det er, ja, krop-psyke (Sj3.13)

Deres tilgang er også i høj grad motivationsrettet fremfor at være behandlingsorienteret, og de fokuserer på at understøtte menneskets lyst og trang til at lære frem for en pligt til at være sund. En diætist fra et medicinsk-klinisk organiseret sundhedshus beskriver eksempelvis vigtigheden af at arbejde motivationsrettet således:

Det er ikke fordi, at det er så fagligt tungt det vi laver, men det er meget at hjælpe dem, der ikke lige selv kan finde de ting, og hjelpe med sådan med at finde deres motivation nogle gange, og hjxlpe dem på vej. Hvor jeg er vant til i sygehusverden, der var det mest styret af, hvem der var mest syg, men her foler jeg, at det er mere styret af, hvem der har mest behov til at blive mere selvhjulpne" (S2.47)

Eller som det udtrykkes hos en kandidat i folkesundhed, der arbejder i et lokalt organiseret sundhedshus:

Vores organisation handler meget om at møde borgerne, der hvor de er. Det er det, som mange af mine kollegaer kan. Nu har jeg ikke selv ret mange samtaler vel. Men det de $k a n$, det er at møde borgeren, der hvor de er og give borgeren noget at bygge videre på. Give borgeren rum til at reflektere, og det er det, der gør også at den borger, når vi lige tager mit eget projekt igen, som har en enorm modstand mod at komme herop, og så efter en times samtale faktisk gerne vil være her, fordi de fär lov til selv at bestemme, 
så det er denne her med, at lade kontrollen og ansvaret blive hos borgeren og møde borgeren der, hoor han er. (M3.43)

Sundhed ses på denne måde som mere end motion og fravær af sygdom. Det indebærer en mental tilstand, der involverer hverdagslivet og de sociale betingelser, der omgiver mennesker (kode: reproducerende sundhedspædagogisk diskurs). Evett beskriver dette som hybridprofessionalisme, fordi den netop indeholder to typer af professionalisme: en fag-faglig og en organisatorisk, hvor det traditionelt set er den fag-faglige, der giver social og kulturel status (Evetts, 2011; Weber, 2003).

Der er dog også steder, hvor de sundhedspædagogiske meningssammenhænge bruges af både sundhedsprofessionelle og borgere som opposition til et alt for bredt og diffust sundhedsbegreb. Her er fokus på, at individet er selvansvarlig for sundhed, og at man ikke som sundhedsprofessionel skal overtage ansvaret for deres sundhedsarbejde. Borgere, der trækker på en opponerende sundhedspædagogisk diskurs, undergraver forestillinger om, at lokale samfund har noget med sundhedsvelvære at gøre. De "nye" sundhedsprofessionelle anses ikke som værende legitime udbydere af sundhedsaktiviteter, hvilket de knytter sammen med en ide om, at individet alene bør modtage sundhedsrelaterede aktiviteter i sundhedshusene i forbindelse med konkret rehabilitering (kode: opponerende sundhedspædagogisk diskurs).

Det er særligt de sundhedsprofessionelle og ikke i så høj grad borgerne, der bruger denne diskurs, der blandt andet består af referencer til "social resiliens", "livsnydelse" og "sunde vaner" frem for til lægefaglige dimensioner (kode: sundhedspædagogisk diskurs). En sundhedsprofessionel knytter således spontant en sundhedspædagogisk forståelsesramme sammen med, hvad hun kalder for deres nye "fælles professionalisme". Denne henviser til en bred forståelse af, hvad sundhed er, det vil sige til et ressourcefokus på borgeren og ikke et sygdomsfokus (M1.35). En anden sundhedsprofessionel (diætist) formulerer sin sundhedsforståelse som et spørgsmål om at anerkende, at sundhed aldrig kun er fysisk. Denne, og sundhedsprofessionelle generelt, der eksplicit trækker på denne brede sundhedsforståelse, har på mange måder et klassisk helhedsorienteret perspektiv på menneskets velvære, som man blandt andet kender det fra socialpædagogik og som kommer til udtryk i følgende udsagn:

Hvis du involverer alle aspekter [familie, økonomi, logi, socialt netværk] i din tilgang til en borger, så kan han bedre håndtere de problemer han oplever $i$ samfundet, i forhold til hois vi kun kigger på en lille ting" (M2.32). 
I en sundhedspædagogisk tilgang er det væsentlige ikke, hvad borgeren har af klassificerede problemer, det vil sige, hvilke diagnoser borgeren har, men hvilken adgang til ressourcestærke netværk, der er i det lokale miljø for den pågældende borger. Vægtningen af social resiliens som en forudsætning for et sundt liv får mange af de sundhedsprofessionelle til at beskrive sig selv som "brobyggere" mellem de lokale private tilbud, de lokale samfundsinstitutioner og sundhedshusets sundhedsrelaterede aktiviteter, som også er beskrevet indledende (kode: sundhedsprofessionalisme).

I modsætning til omfanget af brugen af en medicinsk diskurs i materialet så fylder brugen og omfanget af den sundhedspædagogiske diskurs på en anderledes måde. Den er mere signifikant forstået på den måde, at den fylder mere end den medicinske, og den bruges mere af de sundhedsprofessionelle end af borgerne.

\begin{tabular}{|c|c|c|c|c|c|}
\hline & \multicolumn{2}{|c|}{ Medicinsk diskurs } & \multicolumn{2}{|c|}{\begin{tabular}{|l} 
Sundhedspædagogisk \\
diskurs
\end{tabular}} & Total \\
\hline & Procent & $\begin{array}{l}\text { Koderefe- } \\
\text { rencer }\end{array}$ & Procent & $\begin{array}{l}\text { Koderefe- } \\
\text { rencer }\end{array}$ & \\
\hline Borger & $57,31 \%$ & 39 & $42,69 \%$ & 26 & $100 \%$ \\
\hline $\begin{array}{l}\text { Professio- } \\
\text { nel }\end{array}$ & $36,24 \%$ & 77 & $63,76 \%$ & 132 & $100 \%$ \\
\hline Total & - & 116 & - & 158 & \\
\hline
\end{tabular}

Tabel 3: Fordeling af diskurskodning i materialet. Celleindhold: Procentvis fordeling af diskurskodning for borgere og sundhedsprofessionelle, samt antal af kodereferencer for henholdsvis medicinsk og sundhedspædagogisk diskurs.

Tendensen i materialet er således, at borgerne ikke bruger den brede sundhedspædagogiske diskurs i lige så høj grad som de sundhedsprofessionelle. De er mere tilbøjelige til at tænke sundhed i meningssammenhænge, der involverer en medicinsk praksis og herunder en diagnostisk kompetence til målrettet medicinsk behandling. Borgerne fremstår på den måde som mere medicinsk orienteret end de sundhedsprofessionelle, omend det overvejende billede er, at begge grupper taler i både medicinske og i sundhedspædagogiske sammenhænge. Det kan antyde, at der sprogligt er spor af borgeranerkendelse af de sundhedsprofessionelle, hvilket igen kan betyde, at professionen har en vis kulturel status i de lokale samfund. 
Spørgsmålet er om de meningssammenhænge, der kommer frem, på nogen måde knytter sig til den måde, hvorpå sundhedshusenes fysiske rammer er organiseret på? Både Foucault, Goffman, Dubois og Parsons studier af, hvad der udvikler en profession og et menneskes professionelle identitet, understregede, som indledningsvist redegjort for, betydningen af fysiske rammer.

\section{Meningssammenhænge, præferencer og rammer}

I forhold til at forstå hvordan de fysiske rammer påvirker de sundhedsprofessionelles professionalisme, så viser ovenstående analyse, at det medicinsk-kliniske falder sammen med en stærkere tilknytning til det mediciske felt, mens det ikke i lige så høj grad gør sig gældende for de professionelle, der arbejder i de lokalt forankrede sundhedshuse.

Sundhedsprofessionelle, der arbejder i medicinsk-kliniske organisatoriske sammenhænge, bliver fremskyndet til primært at se dem selv som fagprofessionelle med specialiserede borgerrettede behandlingsopgaver, mens de normative og kulturelle konventioner i lokalt forankrede huse er mere i tråd med sociale mål så som at skabe et offentligt værested, hvor de lokale borgeres behov for sundhedsydelser kan blive set og hørt. Denne forskel udtrykkes præcis i sondringen mellem det medicinsk-kliniske og det lokalt-forankrede sundhedshus (se tabel 2). Denne sammenhæng mellem de aktiviteter, der foregår i sundhedshusene, og den måde de ansatte opfatter sig selv på som professionelle, er nogle steder meget tydelig, mens ovenstående analyser af meningssammenhænge om sundhed viser en underliggende lighed på tværs af de forskellige typer af sundhedshuse og dermed på tværs af de sundhedsrelaterede aktiviteter, der tilbydes i de 19 sundhedshuse. Det tyder på, at der foregår en professionel integration på tværs af huse og aktiviteter og at denne integration ser ud til at få sin primære kraft fra det medicinske felt eller mere præcist fra en bevidst afstandstagen hertil, som ovenstående analyse også viste.

De sundhedsprofessionelle, der arbejder i sundhedshusene, forsøger alle at adskille sig selv og deres arbejdsopgaver fra en klinisk domineret praksis, som den ser ud på et hospital eller en lignende medicinsk domineret klinik. Men det "lykkes" mere for de sundhedsprofessionelle, der arbejder i et lokalt forankret sundhedshus. Her nødes interaktionen mellem de sundhedsprofessionelle og borgerne til at handle om læring, motivation og livsnydelse fremfor om behandling, målrettet træning og en mere indstuderet professionel-patient interaktion (forfat- 
teren 2015). Forstået gennem Goffmans termer så iscenesætter de lokalt forankrede sundhedshuse således helt andre roller og interaktioner, end det viser sig i de medicinsk-klinisk organiserede huse (E. Goffman 1922-1983, 1990: 34).

Selvom hverken borgerne eller de sundhedsprofessionelle har erfaringer med andre huse end deres eget, så foretrækker begge grupper det lokale sundhedshus med fri adgang til aktiviteter, og som adskiller sig mest fra et hospitals fysiske rammer. De sundhedsprofessionelle opfatter det lokale sundhedshus beskrevet i vignette A som en bedre organisatorisk ramme for at møde borgerne positivt, og borgerne foretrækker den frie adgang frem for den lægeregulerede adgang beskrevet i vignette B. De fleste borgere, der kommer i sundhedshusene, har ikke en diagnose, der kan give dem adgang til hospitalsservice eller til service fra en almen praktiserende læge. De associerer sundhedsprofessionalisme med en medicinsk diskurs og følgelig med eksperter fra det medicinske felt, der har diagnostiske færdigheder og kompetencer. De forventer med andre ord ikke at møde, hvad Evetts kalder for, en hybrid-professionel, som de reelt kommer til at møde i sundhedshusene (kode: vignetrespons) (Evetts, 2011).

Kodningen af vignetresponsen viser som sagt, at både borgere og sundhedsprofessionelle foretrækker det lokale sundhedshus uanset hvilken type, de selv er tilknyttet i dagligdagen. Idet vignetterne spejler de faktiske forskelle blandt sundhedshusene, er det svært endeligt at afgøre, om de reagerer på deres egne omgivelser eller på vignetterne. Dog kan man sige, at netop fordi de alle foretrækker det lokalt forankrede sundhedshus, så taler dette for, at det ikke er deres egne omgivelser, der entydigt bestemmer deres reaktioner på vignetterne. Hvor borgerne er tiltrukket af den frie adgang til det lokale sundhedshus, så foretrækker de sundhedsprofessionelle det lokale sundhedshus, fordi her er en bredere ramme for hvilke typer af aktiviteter, der kan tilbydes. Derudover begrunder de deres præference med, at borgerne i det borgernære sundhedshus forventes at være mere engagerede i deres egen sundhed og dermed i aktiviteterne sammenlignet med "patienterne" i det kliniske hus. Selv om en del af de sundhedsprofessionelle bider mærke i, at der nok vil være en eller anden kontrolmangel og ledelseshul i det lokale sundhedshus, så vægter de alligevel de fordele højere end de fordele de bemærker, der er ved det medicinsk-kliniske hus (blandt andet større kontrol med målgrupper og aktiviteter). 


\section{Diskussion og konklusion}

Kommunernes organisering af de nye sundhedsaktiviteter har haft betydning for de sundhedsprofessionelles sundhedsforståelse på forskellige måder. De nye sundhedsprofessionelle har fået et administrativt mandat fra kommunen til at varetage en række ikke klart definerede opgaver, og de gør det uden "diagnosen" som klassificerende og statusgivende redskab. De bruger i stedet for et netværksredskab qua deres sociale status i det kommunale system til at skabe adgang til service og foranstaltninger for borgerne. De er altså langtfra som betjente uden pistoler eller lærere uden bøger. De er sundhedsprofessionelle med netværk og fysiske rammer til at fremme sundhed og forebygge sygdom. Analysen viste tegn på, at de sundhedsprofessionelle udvikler en række bedømmelseslogikker, der erstatter "diagnosen" som klassificerende redskab. For eksempel vurderer de i højere grad, om borgerne er motiverede til at ændre livsstil og sundhedsopfattelse, end de vurderer deres sygdomsbillede og konkrete behandlingsbehov. Analysen viste også, hvordan nogle sundhedsprofessionelle bevidst fravælger diagnosen som pejlemærke i deres borgervurdering, fordi den diagnostiske klassifikation modarbejder deres sundhedsfremmende arbejde.

Observationerne af de 19 sundhedshuse viste to typer af sundhedshuse, som adskiller sig fra hinanden. Det medicinsk-kliniske sundhedshus, der kæmper en mere eksplicit kamp mod det etablerede sundhedssystem, mens det lokalt organiserede sundhedshus i højere grad kæmper for at blive kendt som tilgængelig ressource i de lokale samfund.

De fysiske rammer ser nok ud til at betinge meningssammenhænge om sundhed, men ikke så tydeligt som forventet. Både borgerne og de sundhedsprofessionelle foretrækker det lokalt organiserede sundhedshus, om end af forskellige grunde. Borgerne trækker hovedsagelig på en medicinsk diskurs omkring sundhed, og nogle ser sundhedshuset som en mulighed for at få adgang til sundhedsaktiviteter uden om sundhedsvæsnets henvisningssystem.

Vignetanalysen bekræfter dette, idet den viste, at såvel borgere som sundhedsprofessionelle ser en fordel i det lokalt organiserede sundhedshus uanset karakteren af de fysiske rammer, de er i til daglig. Den forskel, der er mellem vignetreaktionerne og de meningssammenhænge, de giver udtryk for, understøtter tesen om, at fysiske rammer betinger adfærd og forventninger. Selvom de fleste således foretrækker det lokalt organiserede sundhedshus, så er deres forventninger og forståelse af, hvad de skal i sundhedshuset indlejret i de rammer, de allerede er en del af. Rammerne betinger på denne indirekte måde de forventninger, aktiviteter, 
men også den sundhedsforståelse, der dominerer både blandt de interviewede sundhedsprofessionelle og blandt de interviewede borgere.

Teoretisk bidrager analyserne til en mere kritisk forståelse af forholdet mellem klassifikationsmagt (diagnosticering) og professionalisme i mødet mellem profession og borger, som det er begrebsliggjort af blandt andet Talcott Parsons og Julia Evetts. Grænserne for, hvad der er politisk muligt at "tegne" ovenfra, er ikke bare trukket af administrative, organisatoriske og fysiske rammer, men også af kulturelle hierarkier om for eksempel sundhed, der rækker udover de allerede etablerede sundhedsprofessioner. Et sådant hierarki "ordner" ikke bare de professionelles administrative rutiner og deres verdensforståelse. Det påvirkes også selv af borgernes selv- og sundhedsforståelse, og det vil sige, af den anerkendelse eller mangel på samme, der, ifølge Weber og de magtorienterede teorier om professionerne og deres udvikling, udgør professioners kulturelle status. Webers sondring mellem social og kulturel status fanger ikke anerkendelsen fra andre professioner som en særskilt forudsætning for, at det kan lykkes for, hvad Evett kalder for en ny hybridprofession at optjene professionsstatus på et marked med professionelle ydelser, der både reguleres statsligt og civilsamfundsligt. Analyserne viste her, at de sundhedsprofessionelle og deres "fælles professionalisme" anerkendes af borgerne (tegn på kulturel status) og i lovgivningen (social status), men ikke i mødet med de etablerede sundhedsprofessioner som eksempelvis almen lægepraksis.

Spørgsmålet er, hvad det betyder for den videre udvikling af en kommunal sundhedsprofessionalisme, der, qua sin kommunale forankring, udover at være svagt koblet til staten også udfordres af den etablerede lægefaglige profession. Med Weber i hånden ser det ud til at blive en hård kamp om status, mens det med Parsons funktionelle professionsforståelse må forventes afgjort af langt flere faktorer end kulturelle og sociale styrkeforhold. En profession er her ikke bare resultatet af anerkendelse af en skolastisk øvelse, men det er et kerneelement i samfundets fortsatte normative orden og således også bundet af den bredere samfundsmæssige og politiske udvikling. Ikke mindst af den politisk-administrative rammesætning af forholdet mellem stat, profession, civilsamfund og borger, der kommer til at tegne fremtidens sundhedsprofessionelle scene. 


\section{References}

Abbott, A. (1988). The system of professions : An essay on the division of expert labor. Chicago: University of Chicago Press.

Charmaz, K. (2006). Constructing grounded theory. A practical guide through qualitative analysis (2nd ed.). London: SAGE Publications.

Dubois, V.,1966-. (2010). The bureaucrat and the poor : Encounters in french welfare offices. Burlington, VT: Ashgate.

Durkheim, E., \& Turner, B. S. (1992). Professional ethics and civic morals [Leçons de sociologie physique des moeurs et du droit] (2. ed. / with a new preface by Bryan S. Turner ed.). London: Routledge.

Evetts, J. (1999). Professionalisation and professionalism: Issues for interprofessional care. J Interprof Care, 13(2), 119-128. doi:10.3109/13561829909025544 https:/doi.org/10.3109/13561829909025544

Evetts, J. (2011). A new professionalism? challenges and opportunities. Current Sociology, 59(4), 406-422. doi:10.1177/0011392111402585

https:/doi.org/10.1177/001139211140258

Foucault, M. (2001). Socialmedicinens fødsel. Distinktion, 2001(3), 11-24, 133. https:/doi.org/10.1080/1600910x.2001.9672797

Foucault, M.,1926-1984. (2000). Klinikkens fødsel [Naissance de la clinique]. København: Hans Reitzel.

Freidson, E.,1923-. (2001). Professionalism : The third logic. Cambridge: Polity.

Freidson, E.,1923-2005. (2007). Professional dominance : The social structure of medical care (1. pbk. ed. ed.). New Brunswick, NJ: Aldine Transaction.

Goffman, E. (1963). Behavior in public places. notes on the social organization of gatherings. New Yoork: The Free Press.

Goffman, E.,1922-1983. (1990). The presentation of self in everyday life. Harmondsworth: Penguin.

Goffman, E., \& Helmreich, W. B. (2007). Asylums : Essays on the social situation of mental patients and other inmates (New ed. ed.). New Brunswick, N.J.: Aldine Transaction.

Harrits, G. S., \& Larsen, L. T. (2016). Professional claims to authority: A comparative study of danish doctors and teachers (1950-2010). Journal of Professions and Organization, doi:10.1093/jpo/jov011 https:/doi.org/10.1093/jpo/jov011

Lipsky, M. (2010). Street-level bureaucracy - dilemmas of the individual in public services. 30th anniversary, expanded edition. New York: Russell Sage Foundation.

Lofland, J. (2006). Analyzing social settings : A guide to qualitative observation and analysis. Belmont, Calif.: Wadsworth/Thomson.

Lund, R., Christensen, U.,f.1953-07-12, \& Iversen, L.,f.1948 (Eds.). (2011). Medicinsk sociologi : Sociale faktorers betydning for befolkningens helbred (2. udgave ed.). Kbh.: Munksgaard Danmark.

Miles, M. B., Huberman, A. M., \& Salda-a, J. (2014). Qualitative data analysis : A methods sourcebook (3rd ed.). Thousand Oaks, CA: Sage.

Parsons, T. (1975). The sick role and the role of the PhysicianReconsidered The Milbank Memorial Fund Quarterly. Health and Society, 53(3), 257-278.

https:/doi.org/10.2307/3349493 
Parsons, T. (1964). The social system. London: The Free Press of Glencoe.

Pedersen, B. M.,f.1955-07-20, \& Rank Petersen, S. (Eds.). (2014). Det kommunale sundhedsvæsen (1. udgave ed.). Kbh.: Hans Reitzel.

Schott, C., Van Kleef, D., \& Noordegraaf, M. (2015). Confused professionals?: Capacities to cope with pressures on professional work. Public Management Review, , 1-28. https:/doi.org/10.1080/14719037.2015.1016094

Sciulli, D. (2009). Professions in civil society and the state: Invariant foundations and consequences. Leiden: Brill.

https:/doi.org/10.1163/ej.9789004178311.iii-488

Starr, P.,1949-. (1982). The social transformation of american medicine. New York: Basic Books.

Sundhedsministeriet. (2010). Sundhedsloven. LBK nr 913 af 13/07/2010. København: Sundhedsministeriet.

Tønnesen, H., \& Det Nationale Begrebsråd for Sundhedsvæsenet. Arbejdsgruppen vedrorende Forebyggelse,Sundhedsfremme og Folkesundhed. (2005). Terminologi : Forebyggelse, sundhedsfremme og folkesundhed (Version 1 ed.) Sundhedsstyrelsen.

Weber, M. (1994). The profession and vocation of politics. In P. Lassman, E R. Speirs (Eds.), Weber: Political writings (). Cambridge: Cambridge University Press.

Weber, M. (2003). Magtfordelingen inden for fællesskabet. klasser, stænder, partier. Udvalgte tekster, bind 2. (pp. 29-43). København: Hans Reitzels Forlag.

Weiss, R. S. (1994). Respondents: Choosing them and recruiting them Learning from strangers: The art and method of qualitative interview studies (pp. 15-37). New York: Free Press.

Wilensky, H. L. (1964). The professionalization of everyone? American Journal of Sociology, 70(2), 137-158. doi:10.1086/223790

https:/doi.org/10.1086/223790 